\title{
PAPER BRAZILIAN FIRMS MARKET POWER IN THE WORLDWIDE MARKET ${ }^{1}$
}

\author{
Giovanna Miranda Mendes ${ }^{2 *}$, Vanessa da Fonseca Pereira ${ }^{2}$ and Marcelo José Braga ${ }^{3}$
}

\footnotetext{
${ }^{1}$ Received on 03.10.2012 accepted for publication on 31.05.2016.

${ }^{2}$ Universidade Federal de Viçosa, Programa de Pós-Graduação em Economia Aplicada, Viçosa, MG - Brasil. E-mail: <giovannamendes@yahoo.com.br>and <vanessadafonsecapereira@gmail.com>.

${ }^{3}$ Universidade Federal de Viçosa, Departamento de Economia Rural, Viçosa, MG - Brasil. E-mail: <mjbraga@ufv.br> *Corresponding author.
}

\begin{abstract}
The objective of this study was to analyze the behavior of Brazilian paper companies in the international market. The analysis was based on the New Empirical Industrial Organization, based on Bresnahan's model (1982) to measure the conduct parameter in the industry. Two-Stage Least Squares (2SLS) method was used for the simultaneous equations estimative. From the results, it cannot be stated that the Brazilian companies behave as a monopolist or as a company in perfect competition in the international market. The parameter of 0.22 in the industry conduct indicated that the market is an oligopoly, intermediary to both extreme behaviors.
\end{abstract}

Keywords: Market structure; Paper; Simultaneous equations.

\section{PODER DE MERCADO DAS EMPRESAS BRASILEIRAS DE PAPEL NO MERCADO MUNDIAL}

\begin{abstract}
RESUMO - Neste trabalho, buscou-se analisar o comportamento das empresas brasileiras de papel no mercado mundial. A análise foi baseada na Nova Organização Industrial Empírica, conforme modelo proposto por Bresnahan (1982), para mensuração do parâmetro de conduta na indústria. Utilizou-se o método de Mínimos Quadrados em Dois Estágios (MQ2E) na estimativa das equações simultâneas. Pelos resultados, não se pode afirmar que as firmas brasileiras no mercado internacional apresentam comportamento de monopólio ou concorrência perfeita. O parâmetro de 0,22 de conduta da indústria indicou que o mercado é um oligopólio, intermediário nos dois extremos de conduta.
\end{abstract}

Palavras-chave: Estrutura de mercado; Papel; Equações simultâneas.

\section{INTRODUCTION}

Given the expansion of the world market for paper and cellulose, which occurred from the 1990s, the Brazilian industry has achieved a prominent position in the industry. In 2009, according to data from the Associação Brasileira de Celulose e Papel - BRACELPA(2011), the paper industry ranked nineth among world producers, while the cellulose industry is the fourth largest producer in the world. In $2011,59 \%$ of cellulose production was intended for foreign markets, the main destinations being the countries of Europe, North America and China. Regarding exports of paper, $21 \%$ of the production was destined for foreign markets, the main buyers were countries of Latin American, Europe and North America (BRACELPA, 2012).

In Brazil, the flow of exports of paper and cellulose increased by $190.4 \%$ between 2000 and 2011 , according to the Associação Brasileira de Produtores de Florestas Plantadas (ABRAF, 2012). Possible reasons for the increase in production and Brazilian

Revista Árvore, Viçosa-MG, v.40, n.4, p.595-602, 2016 http://dx.doi.org/10.1590/0100-67622016000400003 
exports are gains of scale, improvement in the quality of the product, increased competitiveness and gains in shares in foreign markets.

As regards the structure of the domestic industry, a significant number of companies was found, indicating that the sector is not concentrated. There are 222 companies operating in 18 Brazilian states (ABRAF, 2012). In 2008, the four largest companies - Suzano, Klabin, VCP and Aracruz - accounted for $37.33 \%$ of production (EXAME, 2008). By analyzing the world situation, it is emphasized that in 2009 , the 10 largest companies in the world concentrated $40.89 \%$ of the total sales of paper and cellulose in the global market, according to Beuningen et al. (2010). It is observed, therefore, that world supply is decentralized.

Since 2000, the sector has undergone significant restructuring. Mattos and Valença (1999) stated that, although the sector is traditional and conservative all over the world, great cycles of mergers and acquisitions have occured. The new competitive environment required minimum scales of higher and higher production to meet demand, and the increasing unit investment costs required greater financial and administrative capacity of domestic groups, making it difficult the permanence of small companies. Moreover, it is possible that the established companies, resulting from the mergers and acquisitions, gain greater control over the market and prices, due to factors related to barriers to entry of the products. Thus, in the paper market, two main aspects are observed: the existence of economies of scale and the favoring of the largest companies, as regards the granting of funding. Pinho and Avellar (2002) pointed out that economies of scale are derived from the distribution of the products, since paper consumers are relatively sprayed. Surely, the high investments required for the establishment of the production system should also be highlighted, since the minimum scale for the operation of companies is significant. Therefore, if on one hand, the low concentration is a contrary indicative to the existence of market power in the sector, on the other hand, the growth of mergers and acquisitions and the above mentioned barriers to entry of the products suggest the possibility that companies exercise this power, acting with monopolistic behavior. From the results, it is expected to provide relevant information on the competitive dynamics of the sector for researchers and policy decisions aimed at the paper and cellulose industry in order to ensure competitiveness, concurrence and the continued growth of Brazilian exports and consequently, the generation of income and employment.

To achieve the proposed goal, this work is divided into three sections, besides this introduction. The second section presents the methodology, where the theoretical referential, analytical referential, econometric procedures and description of the data used in here. Following are the results and discussion; and, finally, the conclusions.

\section{MATERIALAND METHODS}

\subsection{Theoretical Referential}

Industrial Organization aims to study the behavior of companies in the industry and the markets. Initially, there were two approaches to identify market power: the Structure-Conduct-Performance model (E-C-P) and the Chicago School. However, according to Martin (1993), in the 1970s, the industrial economists began to consider unsatisfactory both approaches.

According to Kupfer and Hasenclever (2002), the New Empirical Industrial Organization has arisen from the application of mathematical methods of Game Theory in business models. The industry's market power has become to be estimated by econometric models, using prices and quantities and maximizing profits. Bresnahan (1982) was the forerunner in the econometric estimation of a parameter for oligopoly solution, in which price and quantity are driven by exogenous variables, reflecting in the market power even in the absence of data on costs and profits.

\subsection{Analytical Reference}

The market power parameter was estimated by the standard structural econometric method, based on the study of Deodhar and Pandey (2008), which presented a special case of the model suggested by Bresnahan (1982).

Considering a duopoly in the market, the Company 1 expects the company 2 produces $2 q^{e}{ }_{2}$. If Company 1 produces $q_{1}$ units, then the total product that is expected to sell in the market will be given by $Q=q_{1}+q_{2}^{e}$, and the maximization problem of the profit of the Company 1 described in equation 1 .

$$
\operatorname{Arg} \max \left[P(Q) q_{1}-c_{1}\left(q_{1}\right)\right]
$$

where $\mathrm{P}(\mathrm{Q})$ is a function of the inverse demand and $c_{1}\left(q_{1}\right)$, the function of total cost of Company 1 . And the first order condition of this problem is: 


$$
P(Q)+\left[\frac{d P}{d Q} \frac{d Q}{d Q_{1}}\right] q_{1}=C m a_{1}\left(q_{1}\right)
$$

where $C m a_{I}$ (.) is the marginal cost of Company 1. When dealing the derivatives as discrete changes, the change in $\mathrm{Q}$ may be expressed by $d Q=d q_{1}+d q^{\mathrm{e}}{ }_{2}$, thus:

$$
\frac{d Q}{d q_{1}}=\left[1+\frac{d q_{2}^{e}}{d q_{1}}\right]
$$

At the balance $d q_{2=}^{e} q_{2}$, the balance expression. (equation 2) becomes:

$$
P(Q)+\frac{d P}{d Q}\left[1+\frac{d q_{2}}{d q_{1}}\right] q_{1}=C m a_{1}\left(q_{1}\right)
$$

The term $\frac{d q_{2}}{d q_{1}}$ is the conjectural variation, referred to as $\mathrm{V}$, and informs about how much Company 1 assumes that Company 2 change its production when Company 1 makes small changes in its produced quantity. Assuming that the companies have identical cost structures and, therefore, produce the same level of product, equation 4 can be generalized to a market with $n$ companies, according to Equation 5.

$$
P(Q)+\frac{d P}{d Q}\left[\frac{1+(n-1) V}{n}\right] Q=C m a
$$

The previous equation may be rewritten as follows:

$$
P(Q)+\lambda \frac{d P}{d Q} Q=C m a
$$

where the left side is the perceived marginal revenue and $\lambda$ is the market power parameter, given by

$$
\lambda=\left[\frac{1+(n-1) V}{n}\right]
$$

Equation 6 clearly shows that, if the $\lambda$ value is zero, the price will be equal to the marginal cost; thus, competition will be perfect. In the case of an oligopoly, the parameter will range between 0 and 1 . If the industry is a type of monopoly, $\lambda$ will be equal to 1 .

Based on this theoretical framework, the procedures to estimate the market power parameter can therefore be presented. The following linear demand function is considered:

$$
Q_{t}=\alpha_{0}+\alpha_{1} P_{t}+\alpha_{2} Z_{t}+\varepsilon_{t 1}
$$

Where $Q_{t}$ is the amount, $P_{t}$ is the price, $Z t$ is the vector of exogenous variables and $\varepsilon_{t 1}$ is the term of error. However, in the marginal cost, the functional form is considered, given by:

$$
C M a_{t}=\gamma_{0}+\gamma_{1} Q_{t}+\gamma_{2} W_{t}
$$

where $W_{t}$ is the set of exogenous variables. By substituting the previous equation in (6), the result is:

$$
P_{t}=\gamma_{0}+\gamma_{1} W_{t}+\gamma_{2} Q+\varepsilon_{t 2}
$$

where $\varepsilon_{t 2}$ is the error term and $\gamma_{3}=-\lambda\left[\frac{d P_{t}}{d Q_{t}}\right]$. From the equation 8 , it is found the inclination of the demand inverse function $\left(d p_{t} / d Q_{t}\right)$, represented by the term $1 / \alpha_{1}$. Therefore, the Market power parameter is given by $\lambda=-\alpha_{1} \gamma_{2}$.

The accurate analysis of this parameter requires that hypothesis tests are carried out on the obtained value, which are possible only when the lambda distribution is known. Thus, the Bootstrap procedure proposed by Efron (1979) was carried on, which generated distribution for the lambda parameter.

According to Deodhar and Pandey (2008), this procedure is a non-parametric approach to statistical inference based on resampling of data. The regression errors are saved and resampled at random and with replacement, generating a new dependent variable. Finally, this new created variable is inserted into the regression with the explanatory variables.

\subsection{Econometric procedures}

The determination of price and quantity is made jointly by the system estimation, formed by interdependent structural equation of supply and demand. It is a complete system, since the number of endogenous variables is equivalent to the number of equations, so that presents the equilibrium solution. However, Greene (2002) showed, from the reduced form ${ }^{1}$ of the model that both equations do not satisfy the assumptions of the classical regression model, since there is correlation of endogenous variables with the errors.

In order to solve the problem caused by the simultaneity, the methods of Instrumental Variables (IV), Least Squares in Two Stages (LS2S) or Least Squares in Three Stages (LS3S) can be used. Because of the

Revista Árvore, Viçosa-MG, v.40, n.4, p.595-602, 2016 
difficulty in obtaining the structural standard deviations by IV, in this work, the LS2S method is used. Moreover, the results of IV and LS2S are equivalent to equations exactly identified.

The LS2S is a method with limited information, that is, it is individually applied to each equation and supplies consistent estimators and assintonticaly efficient. To represent its steps, the following model should be considered:

$$
\left\{\begin{array}{l}
Q_{t}=\alpha_{0}+\alpha_{1} P_{t}+\alpha_{2} Z_{t}+\varepsilon_{t 1} \\
P_{t}=\gamma_{0}+\gamma_{1} W_{t}+\gamma_{2} Q_{t}+\varepsilon_{t 2}
\end{array}\right.
$$

Where $Q_{t}$ is the amount, $P_{t}$ is the price, $Z_{t}$ is the set of exogenous variables of the demand equation and $W_{t}$ is the set of exogenous variables of the supply equation. The objective of the first step is to eliminate the correlation between the endogenous explaining variable and the random error in each equation is the estimate by means of MQO of the reduced forms, as it follows:

$$
\left\{\begin{array}{l}
Q_{t}=\alpha_{0}+\alpha_{1} Z_{t}+\alpha_{2} W_{t}+\mu_{t 1} \\
P_{t}=b_{0}+b_{1} Z_{t}+b_{2} W_{t}+\mu_{t 2}
\end{array}\right.
$$

In the second step, the values of endogenous variables, estimated in the first step $(\hat{Q}$ and $\hat{P})$, are used as explaining variables of the model, that is, since they are not correlated with their respective errors. Therefore, the following equations are also estimated by MQO:

$$
\left\{\begin{array}{l}
Q_{t}=\alpha_{0}+\alpha_{1} \hat{P}_{t}+\alpha_{2} Z_{t}+\varepsilon_{t 1} \\
P_{t}=\gamma_{0}+\gamma_{I} W_{t}+\gamma_{2} Q_{t}+\varepsilon_{t 2}
\end{array}\right.
$$

Finally, it is highlighted that, before MQO, the endogeneity in the system of equations should be checked. Therefore, it is performed the Hausman specification test (1978). Additionally, the test of Sargan (1958) was carried out to check whether the instruments used are orthogonal in relation to the estimated residuals. It is an over identification restrictions test, whose null hypothesis is the validity of the chosen instruments, that is, they are not correlated with the error term; and of the correct selection of instruments to be excluded from the estimated equation.

\subsection{Data}

Monthly data were used in the period between January 2000 and October 2008, totaling 106 observations.
The price series and quantity refer to export data of paper to print from Brazil to the world, and they were obtained from the database provided by the Brasil (2011), by means of Aliceweb system.

In the initial specification of the supply equation, a series of variables were used, which are: the price of cellulose short fiber in the State of São Paulo (raw material for paper), obtained in Centro de Inteligência em Florestas - CIF (2011); the commercial exchange rate; the established capacity used, both from the database of the Instituto de Pesquisa Econômica Aplicada - IPEA (2011); the index of the real minimum wage, provided by the Departamento Intersindical de Estatística e Estudos Socioeconômicos - DIEESE, available at the Fundação Getúlio Vargas - FGV (2011); and electricity consumption, consumption of diesel oil and the SELIC interest rate, and the last three were obtained from the Time Series Managed Systems of the Banco Central do Brasil BACEN (2011).

Exports of the United States were used in the demand equation - as a representation of substitute product - provided by Foreign Agriculture Service - FAS (2011) - of the United States Department of Agriculture; the exchange commercial rate; and world income. In the latter, a proxy formed by the sum of exports and imports of goods and services of the Organisation for Economic Co-operation and Development - OECD (2011) was used, based on data provided by the OECD.

\section{RESULTS}

This section presents estimates of demand and supply equations through the Two Stage Least Squares Method (2SLS), which was justified by the simultaneity, identified in the endogeneity test of Hausman (1978).

The model formed by the variables described in the previous section did not provide results consistent with the expectations of economic theory in addition of generating few significant coefficients. The estimate that presented the best adjustments, consistent with economic theory, was obtained from the model represented by the following equation:

$$
\begin{aligned}
& \log (\text { quantity })=\underset{(-)}{\alpha} \log (\text { price })+\underset{(+)^{2}}{\alpha} \log \\
& \text { (income) }+\underset{(-)^{3}}{\alpha} \text { export_eua }+\underset{(+)^{4}}{\alpha} \text { trend, } \\
& \log (\text { price })=y_{0}+\underset{(+)}{y_{1}} \log (\text { quantity })+\underset{(+)^{2}}{y_{2}} \\
& \text { salary }+\underset{(+)^{3}}{y_{3}} p_{\text {celullose }},
\end{aligned}
$$


where quantity is the amount of paper exported by Brazil (in tonnes); price is the price paid per exported ton of paper; income is the world income; export_usa is the amount of paper and cellulose exported by the United States; trend is the linear trend term; salary is the real minimum wage index; and p_cellulose is the pulp prices.

The signs of the coefficients below refer to the expected effect of each variable. Besides the constant, the instruments used in estimating the demand equation were income, trend and export_usa, used as explanatory, and the cost of energy and the rate of capacity utilization established in the industry, excluded from the main model. However, the supply equation was manipulated by salary and $p \_c e l u l o s e$, included as explanatory, and by the energy cost, the utilization rate of installed capacity, the trend and the income.

The results of the regressions estimated of demand and supply represented by the equations 11 and 12 , respectively, are shown in Table 1.

The usual interpretation of $\mathrm{R}^{2}$ does is not applied to models of endogenous variables. Thus, the choice of this model was based on the consistency of the signs of the coefficients with the economic theory of demand and significance of the coefficients.

Elasticities are given by the coefficients, because it is a log-log model. It was noted that the international demand for Brazilian paper is significantly elastic, suggesting that companies are unable to exercise market power in the international scope. Thus, a $10 \%$ increase in price reduces demand on $21.45 \%$. However, the consumption of paper was significant in relation to income, although the elasticity is low. By calculating the elasticity, in the midpoint, there is a variation of $14.52 \%$ in the amount demanded for Brazilian paper, in response to a $1 \%$ increase in global income. Possibly, this is due to the fact it is about printing papers, linked to consumption of equipment and machines and to the access to information technology.

Considering the substituting relation between paper exports from the USA and the Brazilian paper, it was expected negative sign for the coefficient of Export usa variable. However, the relationship found indicated that paper demand of Brazil and the United States has evolved in the same direction. This result indicates that the manufacturing companies of the paper in Brazil and the United States are subject to similar forces in the international market. However, the behavior of prices received by Brazilian companies proved to be inelastic $(0.0026)$ in relation to variations in the quantity supplied.

In addition, the Market parameter (lambda) is given by multiplying $-\alpha_{1} \gamma_{1}$, which resulted in the value of 0.22 . Figure 1 illustrates the histogram of distribution of lambda, obtained by Bootstrap.

Application of Bootstrap procedure generated a series of observations for lambda, whose average value was 0.16 and allowed the realization of hypothesis tests, presented in Table 2.

Table 2 shows that the parameter is statistically different from zero at $1 \%$ of significance, which shows

Table 1 - Estimates of equations of demand and supply of Brazilian cellulose and paper exports.

Tabela 1 - Estimativas das equações de demanda e oferta de exportação de papel e celulose do Brasil.

\begin{tabular}{lccr}
\hline \multicolumn{1}{c}{ Demand } & & \multicolumn{2}{c}{ Supply } \\
\hline Explaining varibables ${ }^{\mathrm{a}}$ & Log (Quantity) & Explaining variables & Log (price) \\
\hline Log (Price) & $-2.1445^{*}$ & Constant & $-4.5765^{*}$ \\
& $(1.1952)$ & & $(0.9874)$ \\
\hline Income & $0.0000^{* * *}$ & Log (Quantity) & $0.1003^{* * *}$ \\
& $(0.0000)$ & & $(0.0584)$ \\
\hline Export_usa & $0.0000^{* * *}$ & Salary & $0.1171^{* * *}$ \\
& $(0.0000)$ & & $(0.1931)$ \\
\hline Trend & $-0.1984^{* * *}$ & P_cellulose & $0.0026^{* * *}$ \\
& $(0.3541)$ & $\mathrm{R}^{2}$ & $(0.0006)$ \\
\hline $\mathrm{R}^{2}$ & 80.37 & Sargan (p-value) & 75.21 \\
\hline Sargan (p-value) & 0.8663 & & 0.6998 \\
\hline
\end{tabular}

Source: Results from the work. Values between parentheses: standard-deviation.

Observations: $* * *$ significant at $1 \%$; significant at $10 \%$

a. The number of the first observations (106) was reduced to 86 because the software disregarded missing observations. 
Source: Results from the study.

Fonte: Resultados da pesquisa.

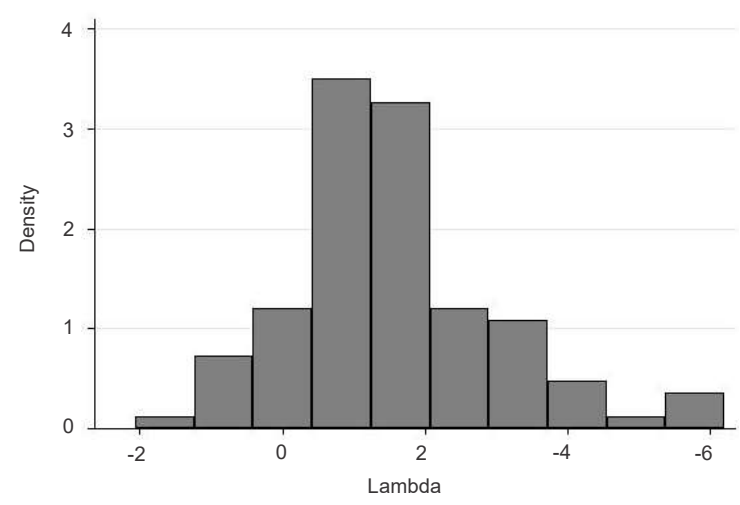

Figure 1 - Lambda's Distribution of frequency.

Figura 1 - Distribuição de frequência do lambda.

that Brazilian paper producing companies, do not behave perfectly competitive in the international market. However, as indicated by the price elasticity of demand, it cannot be said that the Brazilian industry of paper act as a monopoly, since the conduct parameter was statistically less than one. Thus, it can be concluded that Brazilian companies act as oligopolistic structure in the international market.

\section{DISCUSSION}

Other authors analyzed the exports of paper and cellulose sector with different period of time and variables. Soares et al. (2009) estimated supply and demand of export and supply and domestic demand between 1969 and 2005. However, the goal of these authors was to verify only the performance of exports. Thus, the contribution of this paper was to verify the behavior of exports of cellulose and paper in order to analyze market behavior to ensure the existence of competitiveness and continue the growth of Brazilian exports in the international market.

According to the results, restructuring of the sector and the barriers to entry of products were not sufficient to permit the exercise of market power. Therefore, there is evidence that mergers may have been positive by allowing greater gains to producers, as discussed in Mattos and Valença (1999), due to gains of scale and thus, the best competitiveness in foreign markets. In addition, the cycles of mergers, acquisitions and associations increased the productive capacity of the companies and guaranteed better trading conditions in relation to other market participants, such as consumers and their suppliers. However, while Brazilian companies are inserted in this new context, with major operations of mergers and acquisitions, they do not have control of the market.

To analyze this result, it is interesting to point out some information about the market. First, it should be highlighted that only the Brazilian product is being considered and, according to the Bracelpa (2011), the market share of the country in relation to the total paper produced in the international market in 2009 was only $2.54 \%$. In addition, only part of this production is directed to foreign markets, so that, at the international level, the participation of Brazilian companies in the sector is still at low level.

In turn, it is observed that the rejection of perfectly competitive structure is a common result in studies whose objective is to measure market power. Some works on different products also resulted in the absence of conclusive behavior and perfect competition, like the study Deodhar and Sheldon (1997) on the export of soybeans.

\section{CONCLUSION}

From the 1990s, paper and cellulose market has been expanding worldwide. And Brazilian companies have participated in this process with significant increases in production and exports. In addition, there are many companies in this sector operating in the country, which is evidence of the existence of competition in production. However, with the restructuring that took place after 2000, mergers may encourage monopolies, which may increase prices and hinder the entry of new companies,

Table 2 - Hypotheses tests lambda resulting from the Bootstrap procedure.

Tabela 2 - Testes de hipóteses para lambda resultante do procedimento de Bootstrap.

\begin{tabular}{ccc}
\hline Hypothesis & Statistics of test & Result \\
\hline $\mathrm{H}_{0}: \lambda=0 ; \mathrm{H}_{1}: \lambda>0$ Perfect competition & 31.82 & $\mathrm{H}_{0}$ is rejected at $1 \%$ of significance \\
$\mathrm{H}_{0}: \lambda=1 ; \mathrm{H}_{1}: \lambda<1$ Monopoly & -150.00 & $\mathrm{H}_{0}$ is rejected at $1 \%$ of significance \\
$\mathrm{H}_{0}: \lambda=0,5 ; \mathrm{H}_{1}: \lambda=10,5$ Cournot-Nash Behavior & -58.85 & $\mathrm{H}_{0}$ is rejected at $1 \%$ of significance
\end{tabular}

Source: Results of the study. 
reducing competition, increasing the price of products in the market and harming the welfare of consumers of those goods.

The market power parameter showed that the industry structure is a type of oligopoly between companies, since the value of this parameter is intermediate between 0 and 1 , referring to markets with perfect competition type and monopoly, respectively. Therefore, if there is no market power in the paper and cellulose industry, the results are positive for the society, without welfare losses for consumers of these products.

One suggestion for further studies is the estimation of a short and long term model since there are often significant differences in the behavior of companies over time, mainly due to changes in the paper and cellulose industry as well as in world economy.

\section{REFERENCES}

ASSOCIAÇÃO BRASILEIRA DE CELULOSE E PAPEL - BRACELPA. Panorama da Indústria Brasileira de Papel e Celulose. Disponível em: http://bracelpa.org.br Acesso em: março de 2011.

ASSOCIAÇÃO BRASILEIRA DE CELULOSE E PAPEL - BRACELPA. Relatório Estatístico Anual 2010-2011. Disponível em: http:// bracelpa.org.br. Acesso em: março de 2012.

\section{ASSOCIAÇÃO BRASILEIRA DOS PRODUTORES DE FLORESTAS PLANTADAS -.ABRAF. Anuário Estatístico 2012. Disponível em: http://www.bibliotecaflorestal.ufv.br/handle/ 123456789/3910. Acesso em: janeiro de 2012.}

BANCO CENTRAL DO BRASIL - BACEN. Séries Temporais. Disponível em: http:// www.bcb.gov.br/?serietemp Acesso em março de 2011.

BEUNINGEN, R.J.V.; RODDEN, G.; RUSHTON, M.; ZHU, A. The PPI Top 100 - Asian tigers pounce. Pulp \& Paper International, v. 52, n.9, p. 13-18, sep. 2010.

BRASIL. Ministério do Desenvolvimento, Indústria e Comércio Exterior - MDIC. Sistema Aliceweb. Disponível em: aliceweb.desenvolvimento.gov.br. Acesso em: março de 2011.
BRESNAHAN, T.F. The oligopoly solution concept is identified. Economics Letters, v.10, p.87-92, 1982 .

CENTRO DE INTELIGÊNCIA EM FLORESTAS CIF. Cotações. Disponível em: http:// www.ciflorestas.com.br. Acesso em: março de 2011.

DEODHAR, S.Y.; PANDEY, V. Degree of instant competition: estimation of market power in India's instant coffee market. The Indian Economic Review, v.43, n.2, 253-264, 2008.

DEODHAR, S.Y.; SHELDON, I.M. Econometric estimation of the magnitude of market power in the soya meal export market. Journal of Agricultural and Resource Economics, v.22, n.1, 78-86, 1997.

EFRON, B. Bootstrap methods: another look at the Jackknife. The Annals of Statistics, v.7, n.1, p.1-26, 1979.

EXAME. Anuário Exame Agronegócio 2007-2008. São Paulo: 2008. Edição 0879.

FUNDAÇÃO GETÚLIO VARGAS

FGVDADOS. Disponível em: portalibre.fgv.br. Acesso em: março de 2011.

FOREIGN AGRICULTURE SERVICE - FAS.

United States Department of Agriculture (USDA). Disponível em: www.fas.usda.gov. Acesso em: março de 2011.

GREENE, W.H. Econometric analysis. 5. ed. New Jersey: Prentice Hall, 2002.

HAUSMAN, J.A. Specification tests in econometrics. Econometrica, v.46, p.12511271,1978

INSTITUTO DE PESQUISA ECONÔMICA APLICADA - IPEADATA. Disponível em: www.ibge.gov.br. Acesso em: março de 2011.

KUPFER, D.; HASENCLEVER, L. (Org.). Economia industrial: fundamentos teóricos e práticas no Brasil. São Paulo: Campus, 2002.

MARTIN, S. Industrial economics: economic analysis and public policy. 2. ed. New Jersey: Prentice Hall, 1993.

Revista Árvore, Viçosa-MG, v.40, n.4, p.595-602, 2016 
MATTOS, R.L.G.; VALENÇA, A.C. A

reestruturação do setor de papel e celulose. BNDES Setorial, n.10, p.253-268, 1999.

ORGANISATION FOR ECONOMIC COOPERATION AND DEVELOPMENT - OECD.

Statistics. Disponível em:stats.oecd.org. Acesso em março de 2011.

PINHO, M.; AVELLAR, A.P.M. Economias de escala, barreiras à entrada e concentração na indústria de celulose e papel. In: ENCONTRO
NACIONAL DE ENGENHARIA DE PRODUÇÃO ENEGEP, 22., 2002, Curitiba. Anais... Curitiba: 2002.

SARGAN, J. The estimation of economic relationships using instrumental variables, Econometrica, v.26, p.393-415, 1958.

SOARES, N.S.; SILVA, M.L.; VALVERDE, S.R.; LIMA, J.E.; SOUZA, U.R. Análise do mercado brasileiro de celulose, 1969-2005. Revista Árvore, v.33, n.3, p.563-573, 2009. 